\title{
Changes in domestic value added in China's exports: a structural decomposition analysis approach
}

\author{
Yang Lianling ${ }^{1}$ and Yang Cuihong ${ }^{1,2^{*}}$ (i)
}

\author{
${ }^{*}$ Correspondence: \\ chyang@iss.ac.cn \\ ${ }^{1}$ Academy of Mathematics \\ and Systems Science, \\ The Chinese Academy \\ of Sciences, 55 \\ Zhongguancun Dong Lu, \\ Beijing 100190, People's \\ Republic of China \\ Full list of author information \\ is available at the end of the \\ article
}

\begin{abstract}
China's exports can be divided into three types: processing trade, normal trade of goods, and normal trade of services. Based on China's non-competitive input-output table that captures the processing trade, we calculated domestic value added (DVA) in exports for 2002, 2007, and 2010. We then used structural decomposition analysis to examine six factors that could be the driving forces of changes in DVA for exports under the three kinds of trade in the periods 2002-2007 and 2007-2010. The results show that the six driving forces have different effects on exported DVA. Normal trade is the dominant contributor to the increased DVA of China's exports. The increase in DVA generated by exports is due mainly to the expansion of export volume. The most effective way to increase exported DVA sustainably is to expand fabrication effects.
\end{abstract}

Keywords: Non-competitive input-output table that captures processing trade, Domestic value added in exports, Structural decomposition analysis

\section{Background}

After China joined the WTO at the end of 2001, its foreign trade rapidly expanded. Foreign trade has become one of the most important driving forces for China's rapid economic growth. According to the 2002 data released by the National Bureau of Statistics, China's gross exports (including goods and services) were $\$ 365.0$ billion, representing $25.1 \%$ of GDP. By 2012, the share of gross exports in China's GDP grew slightly to $27.2 \%$, but in absolute terms reached $\$ 2.2$ trillion, or five times the total of 2002 , for an average annual growth rate of $20 \%$ over those 10 years. This growth rate was much higher than that of GDP.

Joining the WTO not only expanded China's import and export volumes, it also changed the characteristics of China's trade. The expansion of global trade in past decades is characterized by increasing international fragmentation of production, where production processes are sliced into many different tasks that can be done in different countries. As a result, the total value added is shared by many countries and regions instead of only the final exporters. With these changes in trade characteristics, the standard trade statistics on gross exports no longer give accurate measures of the true value that a country gained from foreign trade. Economists and economic policymakers

(c) The Author(s) 2017. This article is distributed under the terms of the Creative Commons Attribution 4.0 International License (http://creativecommons.org/licenses/by/4.0/), which permits unrestricted use, distribution, and reproduction in any medium, provided you give appropriate credit to the original author(s) and the source, provide a link to the Creative Commons license, and indicate if changes were made. 
are more concerned with accurate measurement of value added generated by trade. To that end, OECD and WTO cooperated to build the OCED-WTO TiVA (Trade in Value Added) database. Since the late 1990s, processing trade has persistently constituted about $50 \%$ of China's exports. Because most of the raw materials and components in processing trade are imported from other countries, a large proportion of gains from exports does not belong to China. Studying the value added generated by China's exports is therefore very important.

With the prevalence of processing trade, any measurement based on aggregate results, combining processing exports and other production, could highly overstate China's economic benefits. Developing a framework to separate the production of Chinese processing exports from general exports so that the total domestic value added (short as DVA) from exports can be measured more accurately is therefore critical. Lau et al. (2006) developed a non-competitive input-output table that captures the Chinese processing trade (known as the DPN table). It differentiates input structures concerning production for domestic use, processing exports, and normal exports, facilitating the study of China's exported DVA. This methodology was subsequently adopted, directly or indirectly and with variations, by other researchers working on similar and related topics (Koopman et al. 2008; Dean et al. 2011; Chen et al. 2012; Duan et al. 2012; Mu and Yang 2014).

Despite the crucial role of exported DVA in aiding our understanding of key issues and trends in foreign trade, little attention has been devoted to the driving forces behind it. This, however, is essential in understanding how China's valued added in trade would change in the long run. In this paper, we not only estimate DVA of China's exports by the DPN model, but also try to determine and quantify the factors that caused exported DVA to change. Such changes may be driven by a variety of factors, such as the expansion of export scale, export structure changes, changes in the structure of exported products, changes in technology, and other factors. Studying the relationship between those factors and the changes in exported DVA could give us a better understanding of what truly influenced the value added in China's exports.

Structural decomposition analysis (SDA) is a widely accepted method developed from the input-output model. It is a useful approach for quantifying the contributions to the driving forces of exported DVA over time. SDA has been used for many problems, such as environmental pollution, consumption growth, and so on (De Haan 2001; Koller and Stehrer 2010; Su and Ang 2012).

Taking into account China's foreign trade issues, Pei applied SDA to Chinese inputoutput tables in order to disentangle and quantify the sources of China's import growth and China's growth in vertical specialization from 1997 to 2005 (Pei et al. 2011). From the point of view of export, by examining the effects of the processing trade, normal trade of goods, and normal trade of services separately, we could determine which kind of trade contributes most to the improving exported DVA. Using SDA, we determined the factors that mostly affect DVA of gross exports and the exports of the three kinds of trade separately. In addition, this is the first study to look at the 2002-2007 and 20072010 periods, which are two very important but different periods in the development of China's exports.

The remaining content is organized as follows. In Sect. 2, we introduce the measurement that uses China's DPN table to estimate exported DVA. Then, we present the 
SDA methodological framework of exported DVA decomposition and provide the data source. Section 3 presents the results of an empirical study using the data of China. Section 4 presents our conclusions.

\section{Methods and data}

\subsection{Methodology of measuring DVA in China's exports with the DPN table}

Lau et al. (2006) developed a modified input-output framework (the non-competitive input-output table for capturing processing trade, also called the DPN table) for China. Its input structures are differentiated among production for domestic use (abbreviated as $D$ ), processing trade (abbreviated as $P$ ), and normal trade (abbreviated as $N$ ). This approach facilitates study of China's exported DVA. The framework of the DPN table is shown in Table 1.

In the table, $X^{D}, X^{P}$, and $X^{N}$ represent the column vectors for total $D, P$, and $N$ output (when it comes to total input, they are row vectors, i.e. the transposed vectors of corresponding total output) $Z^{D D}, Z^{D P}$, and $Z^{D N}$ represent products of production for $D$ as intermediate input by $D, P$, and $N$, respectively. $Z^{N D}, Z^{N P}$, and $Z^{N N}$ represent the products of $N$ used as intermediate input by $D, P$, and $N$, respectively. $Z^{M D}, Z^{M P}$, and $Z^{M N}$ represent the imported products used as intermediate input by $D, P$, and $N$, respectively. $F^{D}, F^{P}$, and $F^{N}$ represent the column vectors of final demand for $D, P$, and $N$, respectively. $V^{D}, V^{P}$, and $V^{N}$ represent the row vectors of value added in production for $D, P$, and $N$, respectively.

$$
\text { If we suppose } X=\left[\begin{array}{c}
X^{D} \\
X^{P} \\
X^{N}
\end{array}\right], \quad Z=\left[\begin{array}{rrr}
Z^{D D} & Z^{D P} & Z^{D N} \\
0 & 0 & 0 \\
Z^{N D} & Z^{N P} & Z^{N N}
\end{array}\right], \quad F=\left[\begin{array}{c}
F^{D} \\
F^{P} \\
F^{N}
\end{array}\right], \quad V=\left[\begin{array}{c}
V^{D} \\
V^{P} \\
V^{N}
\end{array}\right] \text {, }
$$

$M=\left[Z^{M D} Z^{M P} Z^{M N}\right]$, then there are two accounting equations:

$$
\begin{aligned}
& X=\mu Z+F, \\
& X^{\prime}=\mu^{\prime} Z+\mu^{\prime} M+V^{\prime},
\end{aligned}
$$

\begin{tabular}{|c|c|c|c|c|c|c|c|c|}
\hline \multicolumn{3}{|c|}{$\begin{array}{l}\text { Intermediate } \\
\text { use }\end{array}$} & \multicolumn{5}{|l|}{ Final use } & \multirow{2}{*}{$\begin{array}{l}\text { Total } \\
\text { output or } \\
\text { import }\end{array}$} \\
\hline$D$ & $P$ & $N$ & Consumption & $\begin{array}{l}\text { Gross } \\
\text { capital } \\
\text { formation }\end{array}$ & Export & $\begin{array}{l}\text { Other } \\
\text { capital }\end{array}$ & $\begin{array}{l}\text { Total } \\
\text { of final use }\end{array}$ & \\
\hline
\end{tabular}

Table 1 Non-competitive input-occupancy output table for capturing processing trade (DPN table)

$\begin{array}{lllll}\text { Input } & & & & \\ \text { Intermediate } & & & & \\ D & Z^{D D} & Z^{D P} & Z^{D N} & F^{D C} \\ P & 0 & 0 & 0 & 0 \\ N & Z^{N D} & Z^{N P} & Z^{N N} & F^{N C} \\ \text { Imported } & Z^{M D} & Z^{M P} & Z^{M N} & F^{M C} \\ \text { products } & & & & \\ \text { Value added } & V^{D} & V^{P} & V^{N} & \\ \text { Total input } & X^{D} & X^{P} & X^{N} & \end{array}$

$\begin{array}{llll}F^{D \prime} & 0 & F^{D} & X^{D} \\ 0 & F^{P E} & F^{P} & X^{P} \\ F^{N \prime} & F^{N E} & F^{N} & X^{N} \\ F^{M \prime} & 0 & F^{M} & x^{M} \\ & & & \\ & & & \end{array}$

The superscripts $D, P$, and $N$ denote production for domestic use, production for processing trade exports, and production for normal trade exports, respectively 
where $\mu^{\prime}=(1, \ldots, 1)$ denotes the summation row vector; a prime is used to indicate transposition.

$$
\text { Define } A=\left[A_{i j}\right]=\left[\frac{Z_{i j}}{X_{j}}\right]=\left[\begin{array}{rrr}
A^{D D} & A^{D P} & A^{D N} \\
0 & 0 & 0 \\
A^{N D} & A^{N P} & A^{N N}
\end{array}\right] \text { as the matrix of input coefficients, }
$$

Eq. (1) can be written as $X=A X+F$. As with the standard Leontief model, its solution is given by $X=(I-A)^{-1} F=L F$, where $L \equiv(I-A)^{-1}$ denotes the extended Leontief inverse.

If we define the column vector of value added coefficients $D, P$, and $N$ as $A_{v}$, $A_{v}^{\prime}=V^{\prime}(\hat{X})^{-1}$, then we can measure the domestic value added generated by gross exports (i.e., exported DVA) as follows:

$\begin{aligned} \mathbf{v} & =A_{v}(I-A)^{-1} E=A_{v} L E \\ \text { where } E & =\left[\begin{array}{c}0 \\ F^{P E} \\ F^{N E}\end{array}\right] \text { is the column vector of gross exports. }\end{aligned}$

\subsection{Decomposition of exported DVA}

In SDA, the number of possible decomposition formulas is given as n!, where $\mathrm{n}$ denotes the number of variables. Dietzenbacher and Los (1998) recommended that studies should report the mean of all $n$ ! decompositions. In analyzing the changes in DVA generated by gross exports, we applied the principle of polar decompositions (for detail, see De Haan 2001) and hierarchical decompositions (for detail, see Koller and Stehrer 2010) to reduce the number of decompositions.

If we write $B_{v}=A_{v} L$, Eq. (3) can be rewritten as

$$
\mathbf{v}=B_{v} E .
$$

In the first step, the decomposition forms of $\mathbf{v}$ yields

$$
\Delta \mathrm{v}=\frac{1}{2}\left(\Delta B_{v}\right)\left(E_{0}+E_{1}\right)+\frac{1}{2}\left(B_{v 0}+B_{v 1}\right)(\Delta E)
$$

where subscripts 0 and 1 denote time indexes. The first term on the right side of Eq. (5) is interpreted to reflect the fabrication effects; the second term is interpreted to reflect the final demand effects.

If we define $A_{d}$ as the column vector of non-competitive import coefficients of $D, P$, and $N$ with $A_{d}^{\prime}=\left(\mu^{\prime} M\right)(\hat{X})^{-1}$, denote $A_{s}$ as the column sums of matrix $A$ with $A_{s}^{\prime}=\mu^{\prime} A$ Eq. (2) can then change into

$$
\mu^{\prime}=A_{s}^{\prime}+A_{d}^{\prime}+A_{v}^{\prime},
$$

Obviously, $A_{s}, A_{d}$, and $A_{v}$ are fully dependent.

In structural decomposition techniques, the determinants are assumed to be independent. Dietzenbacher and Los (2000) pointed out that dependencies may cause bias in the results of decomposition analyses. They gave some alternative decomposition forms to overcome this problem in general non-competitive input-output models. There are three decomposition forms of $\Delta B_{v}$.

$$
\Delta B_{v}^{1}=\left(A_{v 1} L_{1}-A_{v 0} \tilde{L}_{1}\right)+\left(A_{\nu 0} \tilde{L}_{1}-A_{\nu 0} \breve{L}_{1}\right)+\left(A_{\nu 0} \breve{L}_{1}-A_{\nu 0} L_{0}\right),
$$


with $\quad \tilde{L}_{1}=\left(I-\tilde{A}_{1}\right)^{-1}, \quad \breve{L}_{1}=\left(I-\breve{A}_{1}\right)^{-1}$, where $\quad \tilde{A}_{1}=A_{1}\left(\hat{A}_{s 1}+\hat{A}_{d 1}\right)^{-1}\left(\hat{A}_{s 0}+\hat{A}_{d 0}\right)$, $\breve{A}_{1}=A_{1} \hat{A}_{s 1}^{-1} \hat{A}_{s 0}$

$$
\Delta B_{v}^{2}=\left(A_{v 1} L_{1}-A_{v 0} \tilde{L}_{1}\right)+\left(A_{v 0} \breve{L}_{0}-A_{\nu 0} L_{0}\right)+\left(A_{\nu 0} \tilde{L}_{1}-A_{\nu 0} \breve{L}_{0}\right)
$$

with $\breve{A}_{0}=A_{0} \hat{A}_{s 0}^{-1} \hat{A}_{s 1}\left(\hat{A}_{s 1}+\hat{A}_{d 1}\right)^{-1}\left(\hat{A}_{s 0}+\hat{A}_{d 0}\right)$

$$
\Delta B_{v}^{3}=\left(A_{\nu 1} \tilde{L}_{0}-A_{\nu 0} \breve{L}_{0}\right)+\left(A_{\nu 0} \breve{L}_{0}-A_{\nu 0} L_{0}\right)+\left(A_{\nu 1} L_{1}-A_{\nu 0} \tilde{L}_{0}\right),
$$

with $\tilde{A}_{0}=A_{0} \hat{A}_{s 0}^{-1} \hat{A}_{s 1}$.

The right sides of Eqs. (7a)-(7c) are structured in the same way. The three terms reflect the fabrication effects due to changes of the value added coefficients, the non-competitive import coefficients, and the input mix.

We report the averages over these decompositions as $\Delta B_{v}$, that is:

$$
\Delta B_{v}=\frac{1}{3}\left(\Delta B_{v}^{1}+\Delta B_{v}^{2}+\Delta B_{v}^{3}\right) .
$$

To analyze the effect of different trade types in the value added of exports, we suppose $\bar{E}=\left[\begin{array}{ccc}0 & 0 & 0 \\ E_{P} & 0 & 0 \\ 0 & E_{N} & E_{S}\end{array}\right]$ as an extended matrix of gross exports, where $E_{P}, E_{N}$, and $E_{S}$ represent the column vectors of exports from the processing trade, normal trade of goods, and normal trade of services, respectively. Although the Manual on Statistics of International Trade in Services 2010 divides the processing trade into a kind of manufacturing services on physical inputs owned by others, the processing trade belongs entirely to the goods trade in the DPN model. Thus, we have $E_{P}=F^{P E}$ and $E_{N}+E_{S}=F^{N E}$.

Let $e$ denote the sum of gross exports; that is, $e=\mu^{\prime} \bar{E} \mu$. Let $a^{\prime}=\mu^{\prime} \bar{E}$. Then, the structure matrix of gross exports is defined as $S=\bar{E}(\hat{a})^{-1}$. The row vector $r=\frac{1}{e} \cdot a$ is denoted as the ratio of the three export types (processing trade, normal trade of goods, and normal trade of services). We have:

$$
\bar{E}=e \cdot \bar{E}(\hat{a})^{-1} \cdot \frac{1}{e} \cdot a=e \cdot S \cdot r,
$$

$\Delta \bar{E}$ can be decomposed as follows.

$$
\Delta \bar{E}=\frac{1}{2}(\Delta e)\left(S_{0} r_{0}+S_{1} r_{1}\right)+\frac{1}{2}\left[e_{0}(\Delta S) r_{1}+e_{1}(\Delta S) r_{0}\right]+\frac{1}{2}\left(e_{0} S_{0}+e_{1} S_{1}\right)(\Delta r) .
$$

The first term on the right side of Eq. (9) expresses the change in $\bar{E}$ caused by the export scale. The second term indicates the effects due to change in export structure. The third term shows how the changes in the proportion of three trade types would have affected $\bar{E}$.

We sketched the model mainly by Eqs. (4), (8), and (10). Its hierarchical structure is shown in Fig. 1, and it forms the basis for the decomposition of exported DVA.

\subsection{Data}

For this study, we used China's 2002, 2007, and 2010 DPN tables to estimate the value added embedded in China's total exports. Because sectors changed and are not 


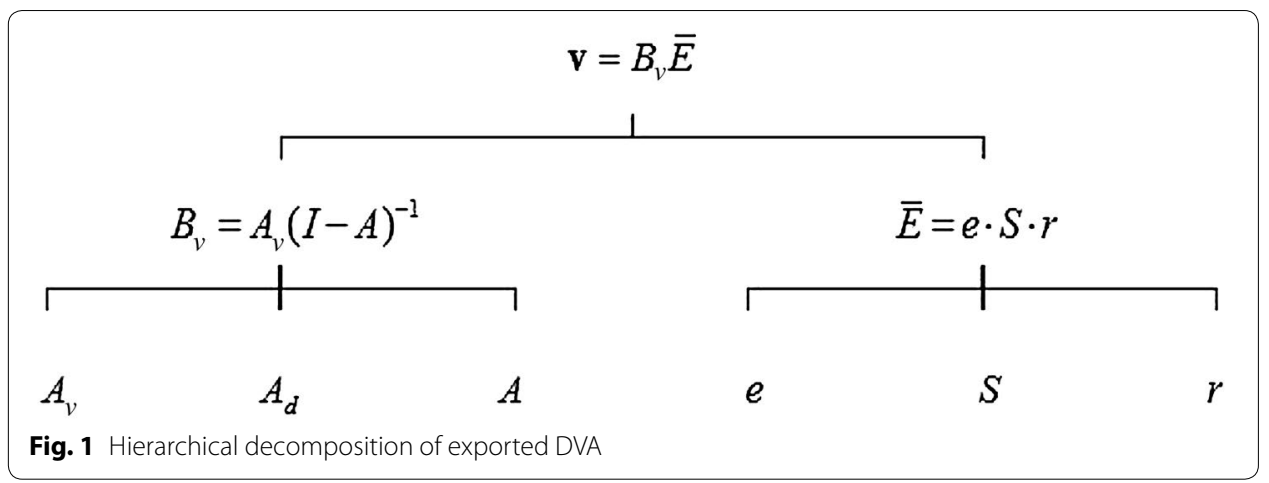

consistent in all three tables, we rearranged the sectors in these tables so that there are 41 sectors in all three trade types: domestic use $(D)$, processing trade $(P)$, and normal trade $(N)$.

Theoretically, we could use the DPN tables directly to compute the value added in China's exports. To analyze the impact of processing trade, normal trade of goods, and normal trade of services on China's exported DVA thoroughly, however, we chose to use exports-of-goods data released by China's General Administration of Customs and services data published by the State Administration of Foreign Exchange. We combined these with the export structure of the $D P N$ table to determine the export structure vector of processing trade $\left(E_{P}\right)$, normal trade of goods $\left(E_{N}\right)$, and services $\left(E_{S}\right)$, respectively. There are two main reasons. First, in the DPN table, processing trade is composed of trade in goods only and therefore exports are listed separately. But for normal trade, export includes trade in goods and services. In other words, trade in goods and trade in services are combined in the same export column in the DPN table. Secondly, the DPN table does not update data in a timely manner. There are, however, official data adjustments. For these two reasons, China's export data (including goods processing trade, normal trade in goods, and in services) were sourced from China's Statistical Yearbook.

Using the SDA formula given in Sect. 2, we analyzed the driving forces behind the changes in exported DVA during the periods 2002-2007 and 2007-2010. During 20022007, China joined the WTO and experienced a rapid economic development in the precrisis period. During 2007-2010, China's export structure changed dramatically because of the financial crisis. Because the factors that drove the changes in value added were mainly structural variables that were little affected by price factors, we used current prices in the $D P N$ tables directly without considering the effects of inflation.

\section{Results}

\subsection{Analysis of changes in China's DVA driven by exports}

Based on the 41 sectors in China's DPN tables for 2002, 2007, and 2010, we estimated DVA embedded in total trade, processing trade, normal trade in goods, and normal trade in services (Table 2).

From the perspective of the composition of gross trade volume, we can find that the proportion of goods exports was much higher than that of services exports. In addition, the proportion of processing exports decreased, the proportion of normal exports 
Table 2 Gross exports and DVA of exports from China in 2002, 2007, and 2010

\begin{tabular}{|c|c|c|c|c|c|c|c|c|}
\hline & & \multicolumn{5}{|c|}{ Volume (billion US\$) } & \multicolumn{2}{|l|}{ Share (\%) } \\
\hline & & Total & $\begin{array}{l}\text { Processing } \\
\text { trade }\end{array}$ & $\begin{array}{l}\text { Normal } \\
\text { trade } \\
\text { in goods }\end{array}$ & $\begin{array}{l}\text { Normal } \\
\text { trade } \\
\text { in service }\end{array}$ & $\begin{array}{l}\text { Processing } \\
\text { trade }(\%)\end{array}$ & $\begin{array}{l}\text { Normal trade } \\
\text { in goods (\%) }\end{array}$ & $\begin{array}{l}\text { Normal } \\
\text { trade } \\
\text { in service } \\
(\%)\end{array}$ \\
\hline \multirow{3}{*}{$\begin{array}{l}\text { Gross } \\
\text { exports }^{\mathrm{a}}\end{array}$} & 2002 & 365.0 & 179.9 & 145.7 & 39.4 & 49.3 & 39.9 & 10.8 \\
\hline & 2007 & 1342.1 & 618.9 & 601.6 & 121.7 & 46.1 & 44.8 & 9.1 \\
\hline & 2010 & 1748.0 & 740.3 & 837.5 & 170.2 & 42.4 & 47.9 & 9.7 \\
\hline \multirow{3}{*}{$\begin{array}{l}\text { Exported } \\
\text { DVA }\end{array}$} & 2002 & 200.2 & 54.9 & 113.7 & 31.6 & 27.4 & 56.8 & 15.8 \\
\hline & 2007 & 798.2 & 226.9 & 469.3 & 102.1 & 28.4 & 58.8 & 12.8 \\
\hline & 2010 & 1102.4 & 285.1 & 673.1 & 144.2 & 25.9 & 61.1 & 13.1 \\
\hline
\end{tabular}

${ }^{a}$ Data source, China Statistical Yearbook

in goods increased gradually, and the proportion of normal trade in services exports initially decreased and then increased. The proportion of the processing trade exports decreased 6.9\% during period 2002-2010 and decreased 3.8\% during 2007-2010.

There are two reasons for this decline. First, due to the impact of the 2008 international financial crisis, the demand for processing exports, especially to Europe and other developed economies, dropped dramatically. Second, China's labor cost rose after 2007, so the comparative advantage in processing trade continued to shrink. In that situation, some multinational companies transferred their production to other Southeast Asian countries, where labor costs were less than in China. This spurred China's industries to transform from the processing trade to the normal trade. In addition, normal trade developed rapidly as well. From 2001 to 2010, the proportion of normal trade in goods to gross exports grew from 39.9 to $47.9 \%$, increasing about 8 percentage points. China's service trade depends on mainly traditional items such as transportation, tourism, and so on. In 2002-2007, trade in goods grew rapidly, leaving trade in services behind. In recent years, however, China has been gradually opening up in its services market and improving the quality of services, especially in financial and other types of new services. China's service exports increased significantly during that period, and its proportion of gross exports also increased.

Processing trade represented a much lower share of total exported DVA. Specifically, the share of processing trade DVA in gross exports was 27.4, 28.4, and 26.0\% in 2002, 2007 , and 2010, respectively. At the same time, normal trade in goods represented the largest share of DVA in gross exports; it was 56.8, 58.8, and $61.1 \%$ in 2002, 2007, and 2010, respectively. The production of processing exports refers to an activity in which raw materials, parts, and components are imported and then processed or assembled into finished products that are exported. The production for processing exports therefore requires imports and thus has a much weaker linkage with other domestic sectors and consequently a much lower valued added than the normal trade. According to the data in Table 2, we can see that each $\$ 1000$ of processing trade export contained only $\$ 385$ of domestic value added in 2010, while in exports of normal trade of goods and trade of services exports, that figure was $\$ 804$ and $\$ 847$, respectively. For the same amount of gross exports, domestic value added in processing trade exports was much 
lower than that of the normal exports. The higher the proportion of processing trade exports, the lower the value added becomes.

The DVA share of China's processing exports is lower than that of normal exports, both goods and services, but it grew rapidly in 2002-2010. In the year 2002, \$1000 worth of processing trade exports contained only $\$ 305$ domestic value added, the normal trade in goods and in services contained $\$ 780$ and $\$ 803$, respectively. DVA for each $\$ 1000$ of China's processing trade increased $\$ 80$ in 2002-2010, more than that of normal trade in goods (\$23) and services (\$44). This indicates that China's processing trade industry upgraded significantly. In the long run, the DVA share of processing trade exports will increase.

\subsection{Disentangling the drivers of change in China's DVA generated by exports}

Using the data of Table 2, we calculated the change in exported DVA during 2002-2007 and 2007-2010 (see Table 3). In 2002-2007, China's exported DVA increased by $\$ 598.0$ billion; in 2007-2010, China's exported DVA increased by $\$ 304.2$ billion.

We found that exports in normal trade of goods were the major contributor to these DVA increases. Specifically, it contributed 59.5 and $67.0 \%$ in periods of 2002-2007 and 2007-2010, respectively. As the proportion of processing exports decreased, the contribution of processing exports to DVA of gross exports decreased by $9 \%$, from 28.8 to $19.1 \%$. Similarly, the proportion of the normal trade of services increased and the contribution of normal trade in services to DVA also increased during these two time periods.

According to the SDA formula given in Sect. 2, we considered the following factors as driving forces of change in exported DVA. They are the change in the value added coefficients $\left(\Delta A_{v}\right)$, change in the import coefficient $\left(\Delta A_{d}\right)$, change in the intermediate inputs $(\Delta A)$, change in the volume of exports or exports scale $(\Delta e)$, change in exports structure $(\Delta S)$, and change in the ratio of three export types (processing trade, normal trade of goods, and normal trade of services) $(\Delta r)$. We arrived at the following result as shown in Table 4.

Table 3 Change of DVA in China exports in period 2002-2007, 2007-2010

\begin{tabular}{|c|c|c|c|c|c|c|c|}
\hline & \multicolumn{4}{|c|}{ Change in exported DVA (billion US\$) } & \multicolumn{3}{|c|}{ Contribution ratios (\%) } \\
\hline & Total & $\begin{array}{l}\text { Processing } \\
\text { trade }\end{array}$ & $\begin{array}{l}\text { Normal } \\
\text { trade } \\
\text { in goods }\end{array}$ & $\begin{array}{l}\text { Normal } \\
\text { trade in ser- } \\
\text { vice }\end{array}$ & $\begin{array}{l}\text { Processing } \\
\text { trade (\%) }\end{array}$ & $\begin{array}{l}\text { Normal } \\
\text { trade } \\
\text { in goods } \\
(\%)\end{array}$ & $\begin{array}{l}\text { Normal trade } \\
\text { in service (\%) }\end{array}$ \\
\hline 2002-2007 & 598.0 & 172.0 & 355.6 & 70.4 & 28.8 & 59.5 & 11.8 \\
\hline $2007-2010$ & 304.2 & 58.2 & 203.8 & 42.1 & 19.1 & 67.0 & 13.8 \\
\hline
\end{tabular}

Table 4 Decomposition of the change in exported DVA: 2002-2007, 2007-2010

\begin{tabular}{llrrrrrr}
\hline & Period & \multicolumn{1}{c}{$\boldsymbol{\Delta} \boldsymbol{A}_{\boldsymbol{v}}$} & $\boldsymbol{\Delta} \boldsymbol{A}_{\boldsymbol{d}}$ & $\boldsymbol{\Delta} \boldsymbol{A}$ & $\boldsymbol{\Delta} \boldsymbol{e}$ & \multicolumn{1}{c}{$\boldsymbol{\Delta}$} & $\boldsymbol{\Delta} \boldsymbol{r}$ \\
\hline Change caused by each factors (billion US\$) & $2002-2007$ & 2.2 & 57.5 & -8.7 & 556.5 & -21.2 & 11.7 \\
& $2007-2010$ & -11.1 & 40.3 & 5.7 & 248.1 & -3.8 & 24.9 \\
Contribution ratios (\%) & $2002-2007$ & 0.4 & 9.6 & -1.5 & 93.1 & -3.5 & 2.0 \\
& $2007-2010$ & -3.6 & 13.3 & 1.9 & 81.5 & -1.2 & 8.2 \\
\hline
\end{tabular}


The expansion of trade volume was the main driving force of DVA growth of China. In 2002-2007, the increase in export volume can explain 93.1\% of the DVA increase. China's trade expanded rapidly during this period, with an average annual growth rate of 29.7\%. In 2007-2010, although its influence decreased, export volume still represented $81.5 \%$ of the change in exported DVA. China's exports were affected by the 2008 financial crisis, resulting in an average annual growth rate of export of around 9\% in 2007-2010.

Change in the structure of gross exports has had a negative effect on China's exported DVA. Although Chinese companies are trying to raise their position in the global value chain by changing their export structure, they still have a long way to go. According to our analysis, changes in the export structure actually lower the percentage of DVA embedded in China's exports. Export structure is an important issue to resolve if one wants to improve the DVA ratio in China's foreign trade.

The change in the ratio of the three kinds of trade in gross exports increased DVA in China's exports. The changes in the proportion of the three kinds of export trade were: (1) the proportion of processing trade decreased, (2) the proportion of normal trade of goods increased, and (3) the proportion of normal trade of service decreased in the first period and increased in the second period. Due to the extensive use of imported parts and components in the processing trade, DVA contained in the processing trade was lower than in other kinds of trade. The decrease in the share of processing trade therefore actually increased the proportion of DVA in total exports. Therefore, as the proportion of processing trade in total exports decreased, the effect of change in the ratio of three export types increased from $2 \%$ in $2002-2007$ to $8.2 \%$ in $2007-2010$.

Overall, the fabrication effects-including change in the value added coefficient, import coefficient, and intermediate input structure-had a minor effect on exported DVA. First, in 2002-2007, upgrading of industrial structure and an increase in labor cost led to an increase in the value added coefficient of industries. The effect of value added ratio on exported DVA was therefore positive, while in 2007-2010 this effect was negative. Second, as Chinese industries transformed, imports used in production decreased. More domestic products were used as substitutions and the import coefficient therefore decreased. This is reflected by the positive impact on exports of value added. Third and finally, during 2007-2010, increasing amounts of domestic raw materials and manufacture-related services were employed in export production. This can be viewed as an indicator of the increasing competitiveness of domestically produced goods. This had a positive effect on exported DVA. Change in the intermediate input structure therefore had a positive effect on exported DVA, contributing 1.9\% in 2007-2010.

The above analysis shows that the contribution of fabrication effects on exported DVA were relatively limited. The increase in exported DVA depended mainly on the rapid expansion of export volume. It is difficult, however, for the export volume to keep expanding at a high rate, so a more effective way to increase exported DVA is to expand fabrication effects. By using more domestic product and less imported components during the production process, and trying to increase the amount of domestic value added in output, we can positively affect exported DVA.

We also analyzed the effects of the three kinds of trade on exported DVA (see Table 5).

Table 5 shows that under different kinds of export, the driving forces have different effects on exported DVA. 
Table 5 Decomposition of the change in exported DVA by three kinds of trade: 2002-2007 and 2007-2010

\begin{tabular}{|c|c|c|c|c|c|c|}
\hline & \multicolumn{6}{|c|}{ Contribution ratios (\%) } \\
\hline & $\Delta A_{v}$ & $\Delta A_{d}$ & $\Delta A$ & $\Delta e$ & $\Delta S$ & $\Delta r$ \\
\hline \multicolumn{7}{|l|}{$2002-2007$} \\
\hline Processing trade & 0.7 & 21.5 & 0.9 & 89.2 & -7.2 & -5.1 \\
\hline Normal trade of goods & 0.04 & 4.4 & -2.3 & 91.0 & -2.3 & 9.1 \\
\hline Normal trade of services & 1.1 & 6.6 & -2.8 & 113.0 & -0.8 & -17.1 \\
\hline \multicolumn{7}{|l|}{$2007-2010$} \\
\hline Processing trade & -2.1 & 36.3 & -1.3 & 114.9 & -10.7 & -37.1 \\
\hline Normal trade of goods & -4.2 & 8.6 & 2.3 & 73.1 & 1.7 & 18.5 \\
\hline Normal trade of services & -3.0 & 4.1 & 4.2 & 76.3 & -2.5 & 20.8 \\
\hline
\end{tabular}

In processing trade, the main driving force is trade volume, and the import coefficient also has a relatively large effect on exported DVA. In fact, the main feature of the processing trade is the use of imported parts and components for assembly. Lower import coefficients mean increased value added coefficients in this sector. This leads to a consumption of more domestic labor and capital. In periods of 2002-2007 and 2007-2010, the effects of import coefficient contributed 21.5 and $36.3 \%$, respectively, to the change in DVA of processing exports.

In China's normal trade of goods and services, the largest driving force is export volume and the ratio of normal trade in gross exports is also an essential factor. During 2002-2010, the proportion of normal trade of goods in China's gross trade increased from 39.9 to $47.9 \%$. Its contribution to the DVA of normal exports of goods was 9.1 and $18.5 \%$, in 2002-2007 and 2007-2010, respectively. In 2002-2007, because of the relatively rapid growth of the goods trade, the proportion of the services trade decreased from 10.8 to $9.1 \%$. Its contribution to DVA of services exports was $-17.1 \%$. In $2007-$ 2010 , the proportion of services trade increased to $9.7 \%$, with a contribution of $20.8 \%$ to the change in DVA of services exports.

Overall, change in value added coefficient had a positive correlation with change in DVA of each kind of export. Using data from China's 41-sector DPN table, we found that in 2002-2007, 22 processing trade industries increase their value added coefficients and the value added coefficients of 37 normal trade industries also increased. In 2007-2010, 16 out of the 41 processing trade industries saw a decrease in their value added coefficients and the value added coefficient also decreased in 39 non-processing trade sectors. In 2002-2007, this factor therefore had a positive effect on exported DVA, while in 2007-2010 it had a negative effect.

In the post-crisis era, the slowdown of world economic growth (especially in the developed economies) decreased demand for Chinese exports, in particular for processing exports. This can be seen from the gradually declining proportion of processing exports in total exports after 2007. Even worse, given the rising unemployment rates in the USA and Europe, trade disputes against Chinese exports may become frequent. This represents an obstacle for China's exports to maintain rapid growth continuously, as occurred in 10 years after China joined WTO. In other words, the growth rate of China's export volume will decrease in the coming years, implying that it is not sustainable to stimulate 
economic growth via unlimited expansion of export scale. Instead, more efforts are required to find ways to raise the DVA ratio of exports in the near future.

\section{Conclusions}

In this study, we used the non-competitive input-output table that captures processing trade to estimate the domestic value added generated by China's gross exports. We have tried to analyze the effects of three types of trade in China's exports: processing trade, normal trade in goods, and normal trade in services. To determine what causes change in the DVA of China's exports, we used SDA and discussed six main factors: the value added coefficients, the import coefficient, the intermediate inputs, the volume of exports or export scale, the export structure, and the ratio of three types of export (processing trade, normal trade of goods, and normal trade of services).

It is clear that the increased contribution of gross exports to China's GDP growth was largely ascribed to the increase in DVA generated by normal exports. This was because DVA generated by processing exports is much lower than that by normal exports. We found, however, that increases in DVA ratio for processing exports exceeded that for normal exports in the period 2002-2010, indicating that China's processing trade involved some kind of industry upgrade.

We also found that the increase in DVA generated by exports was mainly due to the expansion of export volume, whereas the possible upgrading of export structure had no clear positive effect. An effective way to increase exported DVA sustainably is to expand fabrication effects, such as by using more domestic product and fewer imported components during production processes and increasing the amount of domestic value added in output.

The six driving forces have different effects on exported DVA. In processing trade, the main driving force is the trade volume while the import coefficient also has a relatively large effect. Decreasing import coefficients lead to increased DVA of processing exports. In normal trade of goods and services, the largest driving force is export volume, but the ratio of normal trade in China's gross exports is also an essential factor. For each kind of trade, change in the value added coefficient has a positive correlation with change in exported DVA.

To increase DVA in China's exports while maintaining steady growth in trade volume, the focus of China's foreign trade policy should be on export upgrading, trade structure optimization, and increasing the DVA ratio of exports. There are several possible ways to accomplish those goals: promoting the growth of normal exports; encouraging exports by industries with relatively high value added coefficients, especially in the export of services; and upgrading industrial processing by gradually increasing wages and the share of labor compensation in the value added.

\section{Authors' contributions}

YC proposed the idea for the research, YL carried out the model elaborationand empirical analysis, and drafted the manuscript. All authors read and approved the final manuscript.

\section{Author details}

${ }^{1}$ Academy of Mathematics and Systems Science, The Chinese Academy of Sciences, 55 Zhongguancun Dong Lu, Beijing 100190, People's Republic of China. ${ }^{2}$ University of the Chinese Academy of Sciences, A19 Yuquan Road, Beijing, People's Republic of China.

Funding

Funding was provided by Ministry of Commerce of China (Grand No. TAHP-2015-ZB-365) and National Natural Science Foundation of China (Grant Nos. 71673269 and 71125005). 
Competing interests

The authors declare that they have no competing interests.

\section{Publisher's Note}

Springer Nature remains neutral with regard to jurisdictional claims in published maps and institutional affiliations.

Received: 9 April 2017 Accepted: 23 July 2017

Published online: 06 September 2017

\section{References}

Chen X, Cheng LK, Fung KC, Lau L, Sung YW, Zhu K, Duan Y (2012) Domestic value added and employment generated by Chinese exports: a quantitative estimation. China Econ Rev 23(4):850-864

De Haan M (2001) A structural decomposition analysis of pollution in the Netherlands. Econ Syst Res 13(2):181-196 Dean JM, Fung KC, Wang Z (2011) Measuring vertical specialization: the case of China. Rev Int Econ 19:609-625

Dietzenbacher E, Los B (1998) Structural decomposition techniques: sense and sensitivity. Econ Syst Res 10(4):307-324 Dietzenbacher E, Los B (2000) Structural decomposition analyses with dependent determinants. Econ Syst Res 12(4):497-514

Duan Y, Yang C, Zhu K, Chen X (2012) Does the domestic value added induced by China's exports really belong to China? China World Econ 20(5):83-102

Koller W, Stehrer R (2010) Trade integration, outsourcing and employment in Austria: a decomposition approach. Econ Syst Res 22(3):237-261

Koopman R, Wang Z, Wei SJ (2008) How much of Chinese exports is really made in China? Assessing foreign and domestic value-added in gross exports. NBER working paper 14109

Lau L, Chen X, Cheng LK, Fung KC, Pei J, Sung Y, Tang Z, Xiong Y, Yang C, Zhu K (2006) Estimates of US-China trade balances in terms of domestic value-added. Stanford Center for International Development. Working paper no. 295. http://siepr.stanford.edu/publicationsprofile/1059

Mu Z, Yang C (2014) Optimizing China's export structure combining goal programming and non-competitive inputoutput model. J Syst Sci Complex 27(4):712-728

Pei J, Dietzenbacher E, Oosterhaven J, Yang C (2011) Accounting for China's import growth: a structural decomposition for 1997-2005. Environ Plan A 43(12):2971-2991

Su B, Ang BW (2012) Structural decomposition analysis applied to energy and emissions: aggregation issues. Econ Syst Res 24(3):299-317

\section{Submit your manuscript to a SpringerOpen ${ }^{\circ}$ journal and benefit from:}

- Convenient online submission

- Rigorous peer review

- Open access: articles freely available online

- High visibility within the field

- Retaining the copyright to your article

Submit your next manuscript at $\boldsymbol{\nabla}$ springeropen.com 